\title{
The Correlation between Overactive Bladder Symptoms and Urodynamic Findings in Men and Women
}

\author{
MOHAMED S. MOHMOUD, M.D.*; AYMAN M. EDREES, M.D.** and SAYEDA I. ALY, M.D.** \\ The Department of Urology, Al-Zahraa Hospital, Al-Azhar Faculty of Medicine, Al-Azhar University** and \\ El-Sahel Teaching Hospital*
}

\begin{abstract}
Background: Overactive Bladder (OAB) is defined by the International Continence Society (ICS) as urgency, with or without urge incontinence (UUI), usually with frequency and nocturia, if there is no proven infection or other etiology.

Aim of Study: To evaluate the correlation between overactive bladder symptoms (OAB) and urodynamic Detrusor Overactivity (DO) in non neurogenic bladder in both genders.

Patients and Methods: We reviewed the records of 202 patients who attended Al-Zahra'a Univesity Hospital between October 2013 and October 2018 with overactive bladder symptoms urgency, with or without urge urinary incontinence usually with frequency and nocturia, with presence or absence of DO in two groups. All patients were subjected to: Full history taking, voiding diary, clinical examination, laboratory investigations, radiological investigations, urodynamic studies (UDS) and cystoscopic biopsies for histopathological examination. Also we evaluate OAB symptoms, urodynamic parameters with histopathological findings. All patients underwent uroflowmetry: The maximum flow rate, average flow rate and voided volume were recorded. Post Voiding Residual urine (PVR) volume was recorded. Cystometry: The intravesical, intra-abdominal, detrusor pressure, first desire to void, strong desire to void, Maximum Cystometric Capacity (MCC), total volume infused, bladder compliance and detrusor overactivity were evaluated. Cystoscopy and random bladder biopsies from all patients and stained with Hematoxylin and Eosin for histopathological examination of smooth muscle, the urothelium, lamina propria, and adventitia. We used another special stain Massons trichrome to visualize collagen and degenerative changes of smooth muscle bundles.
\end{abstract}

Results: Detrusor overactivity DO was diagnosed in $(63.36 \%) 128 \mathrm{OAB}$ patients after urodynamic studies. Of men $42.9 \%$ and $36.1 \%$ of women with urgency had DO (OAB dry) while $57.1 \%$ of male $63.9 \%$ of female patients with urgency and Urge Urinary Incontinence (UUI) were (OAB wet) had DO. Of women $23.8 \%$ with no DO were also OAB wet having urodynamic Stress Urinary Incontinence (SUI). Combination of symptoms was more precise in predicting $\mathrm{DO}$ in $\mathrm{OAB}$ patients. Patchy areas of myohypertrophic and degenerative

Correspondence to: Dr. Mohamed S. Mohmoud, The Department of Urology, El-Sahel Teaching Hospital histological pattern were observed more in group I in both male and female patients.

Conclusions: We concluded that there was better correlation between $\mathrm{OAB}$ symptoms and the urodynamic diagnosis of DO in women than in men, wet OAB more in women than in men in the same group I. Urgency, frequency and UUI in men, nocturia and UUI in women were significantly increased in predicting DO. Combination of objective parameters from the bladder diary, filling cystometry and histopathological findings have a better correlation with the occurrence of DO.

Key Words: Urodynamic studies - Overactive bladderDetrusor overactivity - Histopathological finding.

\section{Introduction}

OVERACTIVE Bladder (OAB) is defined by the International Continence Society (ICS) as "urgency, with or without urge incontinence (UUI), usually with frequency and nocturia, if there is no proven infection or other etiology" [1].

Urgency is a sudden compelling desire to pass urine, which is difficult to defer. It is the sine qua non for a diagnosis of $\mathrm{OAB}$ [2]. Urgency Urinary Incontinence (UUI): Is defined as involuntary leakage of urine, accompanied or immediately preceded by urgency [3]. Frequent urination and nocturia can be without UUI. As a rule, such patients have sleep disturbances and suffer from depressive and anxiety disorders [4].

Detrusor Overactivity (DO) is a urodynamic observation, characterized by involuntary detrusor contractions during the filling cystometry, which may be spontaneous or provoked. OAB and DO are thus not interchangeable terms, signified by the recognition that $\mathrm{OAB}$ patients undergoing urodynamic testing may not have DO (especially continent OAB patients). Conversely DO seen during urodynamic studies may not be associated with any sensation [4]. The presence of DO during 
UDS must be interpreted in the context of patient symptoms and condition. Ideally, patient symptoms should be reproduced during UDS, so DO would be expected to be accompanied by urgency or urgency incontinence, although it can occur and be significant without being symptomatic, particularly in neurogenic DO. This has been reported in $14 \%$ to $18 \%$ of healthy asymptomatic volunteers undergoing UDS. Conversely, failure to demonstrate DO on UDS does not rule out its existence [5].

The aim of this study is to identify the differences between patients having overactive bladder symptoms with and without detrusor overactivity in non neurogenic bladder in both genders.

\section{Material and Methods}

This prospective study included 202 patients (aged $\geq 18$ years) with overactive bladder symptoms (urinary urgency with or without UUI and frequency or nocturia) were selected from out-patient's urology clinic, Al-Zahra'a Univesity Hospital between October 2013 and October 2018. Informed consent was signed by all enrolled patients. All patients were subjected to: Full history taking, voiding diary, clinical examination, laboratory investigations, radiological investigations, urodynamic studies and cystoscopic biopsies for histopathological examination.

Those with bladder stones, infection, tumors, irradiation, heamaturea, neurological, vesical, bladder outlet and pelvic floor diseases or surgery were excluded.

Patients on antimuscarinic were instructed to stop ingesting them 1 week prior to attending for the test thus providing a washout period and avoiding any interference with test results.

Before urodynamic testing, the patients were instructed to arrive at the urodynamic unit with a comfortably full bladder. All patients underwent uroflowmetry. Maximum flow rate, average flow rate and voided volume were recorded and post voiding residual urine volume (PVR) was recorded using a drainage catheter and measuring container.

After that the patient was placed in the lithotomy position to perform urodynamic testing. Then urodynamic urethral catheter $6 \mathrm{Fr}$ dual-lumen and a rectal catheter were inserted under complete aseptic technique as possible. Transducers were equalized and the bladder was filled at a constant rate of $25 \mathrm{ml}$ per minute using normal saline solution at room temperature for standered UDS.
The first sensation, second sensation, strong desire to urinate and leakage were recorded during filling phase of cystometry.

The intravesical, intra-abdominal and detrusor pressure. First desire to void, strong desire to void, Maximum Cystometric Capacity (MCC), total volume infused, bladder compliance and detrusor overactivity either spontaneous or provoked by coughing or straining many times if normal cystometry were reported.

After obtaining informed written consent for cystoscopy and biopsy from all patients. Random bladder biopsies were taken using cold-cup biopsy forceps. Biopsies were stained with Hematoxylin and Eosin for histopathological examination of smooth muscle, the urothelium, lamina propria, and adventitia. We used another special stain Massons trichrome to visualize collagen and degenerative changes of smooth muscle bundles under light microscopy with 400 magnification power.

The results were statically evaluated and analysed using Statical Progam for Social Science (SPSS) for comparison of the finding between DO and no DO patients, and for comparison between OAB symptoms and UDS finding also with histopathological findings. A binary logistic regression modeling selection process was done with DO as the dependant variable and the potential risk factors including symptoms as possible predictor variables. $p$-value $<0.05$ was considered statically significant.

\section{Results}

This study was conducted on 202 non-neurogenic patients with a mean age $38.63 \pm 13.34$ years (range 18-65 years). After urodynamic studies data were collected. We were dividing those OAB patients into two groups. Group I patients with DO were diagnosed in $63.36 \%$ OAB patients and Group II patients without DO were diagnosed in $36,63 \%$. The incidence of DO was $43.75 \%$ in male and $56.25 \%$ in female OAB patients, respectively with no statistically significant difference between the two groups as regards the age in both genders.

Correlation between OAB reported symptoms and DO of UDS findings in both genders are presented in (Table 1). Urgency, frequency and nocturia were increased with DO in group I more than group II without significant difference while UUI symptom was highly significant increased with DO in group I than group II in both genders.

There were strong relationship between $\mathrm{OAB}$ reported symptoms and UDS parameters in both 
genders as frequency was highly significant associated with low bladder sensation in male patients and significant low MCC in both genders. While in female patients, nocturia was associated with low bladder sensation with higher significance, and low MCC in male patients with significant difference. Nocturia had significant effect on bladder compliance in both genders. However, UUI was highly significant associated with low bladder sensation and MCC in male and highly significant low bladder sensation in female patients with significant low MCC and significant effect on bladder compliance in (Table 2).

In male, 32 of $56(57.1 \%)$ of male DO patients were $\mathrm{OAB}$ wet and 4 of $32(12.5 \%)$ male without DO patients were also wet with highly significant difference. While in female patients, 46 of 72 $(63.9 \%)$ female DO patients were OAB wet and 10 of $42(23.8 \%)$ female without DO patients were also OAB wet having urodynamic Stress Urinary Incontinence (SUI) with highly significant difference in (Table 3).

There was no significant difference between both genders in the two groups regarding DO and histopathological findings. Normal histopathological findings were low $42.96 \%$ in group I compared to $60.81 \%$ in group II in both genders. Myohypertrophic pattern was apperent $57.03 \%$ in group I compared with low similar pattern $39.18 \%$ in group II. Patchy areas of degenerative pattern were observed in $42.18 \%$ in group I while in $31.50 \%$ in group II these patterns were observed with no statistical difference in histopathological findings in (Table 4).

In group I, UUI was the most affecting symptom in morphological changes of urinary bladder; UUI was associated with $79.45 \%$ myohypertrophic and $72.23 \%$ degenerative changes respectively with significantly difference. In group II, nocturia was the most affecting symptom on detrusor muscle in association with $71.11 \%$ myohypertrophic and $79.31 \%$ degenerative changes respectively without significant difference. Frequency also was affected all parameters of histopathological findings of detrusor muscle in both groups in which myohypertrophic changes with frequency increased up to $71.24 \%$ and $62.06 \%$ in group I and group II respectively. And degenerative changes increased as $68.52 \%$ and $69.56 \%$ in group I and group II respectively without statistically difference in (Table 4).

Histopathological changes involving patchy myohypertrophy, patchy degenerations or collagen infiltration of connective tissue might be presented in the same tissue. In group I, patients with myohypertrophic or degenerative changes were associated with low bladder sensation with statistically significant difference and high significant difference in group II. In group I patients' myohypertrophic or degenerative changes were associated with low MCC with high statistical difference compared to group II. Bladder compliance was affected with no statistical difference in the two groups in myohypertrophic or degenerative histopathological patterns in (Table 5).

Table (1): Correlation between overactive bladder symptoms and detrusor overactivity in both genders.

\begin{tabular}{|c|c|c|c|c|c|c|}
\hline \multirow{2}{*}{ Symptoms } & \multicolumn{2}{|c|}{ Male (88) } & \multirow{2}{*}{$\frac{p \text {-value }}{0.004^{*}}$} & \multicolumn{2}{|c|}{ Female (114) } & \multirow{2}{*}{$\frac{p \text {-value }}{0.706}$} \\
\hline & $\begin{array}{c}\text { Group I: } \\
\text { DO } 56\end{array}$ & $\begin{array}{c}\text { Group II: } \\
\text { No DO } 32\end{array}$ & & $\begin{array}{c}\text { Group I: } \\
\text { DO } 72\end{array}$ & $\begin{array}{c}\text { Group II } \\
\text { no DO } 42\end{array}$ & \\
\hline \multicolumn{7}{|l|}{ Urgency: } \\
\hline Positive & $56(100 \%)$ & $32(100 \%)$ & 1.000 & $72(100 \%)$ & $42(100 \%)$ & 1.000 \\
\hline Negative & 00 & 00 & & 00 & 00 & \\
\hline \multicolumn{7}{|l|}{ Frequency: } \\
\hline Positive & $37(66.1 \%)$ & $17(53.12 \%)$ & 0.437 & $45(62.5 \%)$ & $22(52.4 \%)$ & 0.389 \\
\hline Negative & $19(33.9 \%)$ & $15(46.88 \%)$ & & $27(37.5 \%)$ & $20(47.6 \%)$ & \\
\hline \multicolumn{7}{|l|}{ Nocturia: } \\
\hline Positive & $37(66.1 \%)$ & $18(56.3 \%)$ & 0.492 & $53(73.6 \%)$ & $23(54.8 \%)$ & $0.042 *$ \\
\hline Negative & $19(33.9 \%)$ & $14(43.7 \%)$ & & $19(26.4 \%)$ & $19(45.2 \%)$ & \\
\hline \multicolumn{7}{|l|}{ UUI: } \\
\hline Positive & $32(57.1 \%)$ & $4 \quad(12.5 \%)$ & $<0.001 * *$ & $46(63.9 \%)$ & $10(23.8 \%)$ & $<0.001 * *$ \\
\hline Negative & $24(42.9 \%)$ & $28(87.5 \%)$ & & $26(36.1 \%)$ & $32(70.2 \%)$ & \\
\hline
\end{tabular}

Values are presented as numbers $(\%)$. 
Table (2): Association of overactive bladder symptoms and urodynamics findings in men and women patients with OAB.

\begin{tabular}{|c|c|c|c|c|c|c|}
\hline \multirow{2}{*}{ Symptoms } & \multicolumn{3}{|c|}{ Male } & \multicolumn{3}{|c|}{ Female } \\
\hline & $\begin{array}{c}1 \text { st } \\
\text { sensation }(\mathrm{ml})\end{array}$ & $\begin{array}{l}\mathrm{MCC} \\
(\mathrm{ml})\end{array}$ & $\begin{array}{c}\text { COMP } \\
(\mathrm{ml} / \mathrm{cm} \mathrm{H} 2 \mathrm{O})\end{array}$ & $\begin{array}{c}1 \text { st } \\
\text { sensation }(\mathrm{ml})\end{array}$ & $\begin{array}{l}\mathrm{MCC} \\
(\mathrm{ml})\end{array}$ & $\begin{array}{c}\text { COMP } \\
(\mathrm{ml} / \mathrm{cm} \mathrm{H} \mathrm{H})\end{array}$ \\
\hline \multicolumn{7}{|l|}{ Frequency: } \\
\hline Positive & $91.16 \pm 24.61$ & $241.40 \pm 65.18$ & $38.93 \pm 9.92$ & $117.10 \pm 31.62$ & $242.28 \pm 65.42$ & $34.64 \pm 16.65$ \\
\hline Negative & $118.15 \pm 31.90$ & $285.32 \pm 77.04$ & $40.84 \pm 13.79$ & $124.11 \pm 33.51$ & $292.75 \pm 79.04$ & $43.88 \pm 26.45$ \\
\hline$p$-value & $<0.001 * *$ & $0.048 *$ & 0.314 & 0.297 & $0.025^{*}$ & 0.363 \\
\hline \multicolumn{7}{|l|}{ Nocturia: } \\
\hline Positive & $105.74 \pm 28.55$ & $242.63 \pm 65.51$ & $36.21 \pm 17.62$ & $119.11 \pm 32.16$ & $274.50 \pm 74.12$ & $34.09 \pm 15.50$ \\
\hline Negative & $109.69 \pm 29.62$ & $286.87 \pm 77.45$ & $45.92 \pm 11.27$ & $167.40 \pm 45.20$ & $310.50 \pm 83.84$ & $44.76 \pm 20.69$ \\
\hline$p$-value & 0.610 & $0.020^{*}$ & $0.014^{*}$ & $<0.001 * *$ & 0.083 & $0.028^{*}$ \\
\hline \multicolumn{7}{|l|}{ UUI: } \\
\hline Positive & $77.55 \pm 20.94$ & $200.05 \pm 54.01$ & $31.13 \pm 12.41$ & $126.66 \pm 34.20$ & $256.25 \pm 69.19$ & $36.08 \pm 17.04$ \\
\hline Negative & $133.78 \pm 36.12$ & $335.68 \pm 90.63$ & $48.27 \pm 10.74$ & $186.10 \pm 66.45$ & $305.80 \pm 82.57$ & $52.87 \pm 16.17$ \\
\hline$p$-value & $<0.001 * *$ & $<0.001 * *$ & $<0.001 * *$ & $<0.001 * *$ & $0.016^{*}$ & $0.003^{*}$ \\
\hline \multicolumn{7}{|l|}{ Urgency: } \\
\hline Positive & $109.68 \pm 29.61$ & $273.34 \pm 73.80$ & $46.86 \pm 14.25$ & $119.50 \pm 32.27$ & $286.49 \pm 77.35$ & $44.72 \pm 26.67$ \\
\hline Negative & - & - & - & - & - & - \\
\hline$p$-value & - & - & - & - & - & - \\
\hline $\begin{array}{l}\text { Values are pres } \\
\text { UUI : Urge ur } \\
\text { MC : Maxim } \\
\text { Comp : Bladder }\end{array}$ & $\begin{array}{l}\text { as mean } \pm \mathrm{SD} \text { o } \\
\text { incontinenc. } \\
\text { stometric capaci } \\
\text { oliance. }\end{array}$ & bers $(\%)$. & $\begin{array}{l}* p \text {-value }<0.05 \\
* * \text {-value }<0.00\end{array}$ & & & \\
\hline
\end{tabular}

Table (3): Comparison between wet and dry OAB with detrusor overactivity in both male and female.

\begin{tabular}{lcc}
\hline & Male & Women \\
\hline OAB Wet: & & \\
Group I (+DO) & $32(57.1 \%)$ & $46(63.9 \%)$ \\
Group II (-DO) & $4(12.5 \%)$ & $10(23.8 \%)$ \\
$p$-value & $<0.001 * *$ & $<0.001 * *$ \\
OAB Dry: & & \\
Group I (+DO) & $24(42.9 \%)$ & $26(36.1 \%)$ \\
Group II (-DO) & $28(87.5 \%)$ & $32(76.2 \%)$ \\
$p$-value & $<0.001 * *$ & $<0.001 * *$ \\
\hline Values are presented as numbers $(\%)$. & $* p$-value $<0.05 \mathrm{~S}$. \\
OAB wet: Overactive bladder. & $* * p$-value $<0.001 \mathrm{HS}$ \\
DO : Detrusor overactivity. &
\end{tabular}

Table (4): Correlation between histopathological changes with OAB symptoms in both groups.

\begin{tabular}{|c|c|c|c|c|c|c|c|c|}
\hline \multirow{2}{*}{$\begin{array}{l}\text { All } \\
\text { parameters }\end{array}$} & \multicolumn{3}{|c|}{ Group I: DO (n=128) } & \multirow{2}{*}{$\begin{array}{c}p- \\
\text { value }\end{array}$} & \multicolumn{3}{|c|}{ Group II: No DO $(n=74)$} & \multirow{2}{*}{$\begin{array}{c}p- \\
\text { value }\end{array}$} \\
\hline & $\begin{array}{c}\text { Normal } \\
(\mathrm{n}=55) 42.96 \%\end{array}$ & $\begin{array}{l}\text { Hypertrophy } \\
(\mathrm{n}=73) 57.03 \%\end{array}$ & $\begin{array}{c}\text { Degeneration } \\
(\mathrm{n}=54) 47.18 \%\end{array}$ & & $\begin{array}{c}\text { Normal } \\
(n=45) 60.81 \%\end{array}$ & $\begin{array}{c}\text { Hypertrophy } \\
(n=29) 39.18 \%\end{array}$ & $\begin{array}{c}\text { Degeneration } \\
(\mathrm{n}=23) 31.08 \%\end{array}$ & \\
\hline $\begin{array}{l}\text { Urgency: } \\
\text { Positive } \\
\text { Negative }\end{array}$ & $\begin{array}{l}(100.0 \%) \\
0(0.0 \%)\end{array}$ & $\begin{array}{l}(100.0 \%) \\
0(0.0 \%)\end{array}$ & $\begin{array}{l}(100.0 \%) \\
0(0.0 \%)\end{array}$ & 1.000 & $\begin{array}{l}(100.0 \%) \\
0(0.0 \%)\end{array}$ & $\begin{array}{l}(100.0 \%) \\
0(0.0 \%)\end{array}$ & $\begin{array}{l}(100.0 \%) \\
0(0.0 \%)\end{array}$ & 1.000 \\
\hline $\begin{array}{c}\text { Frequency: } \\
\text { Positive } \\
\text { Negative }\end{array}$ & $\begin{array}{l}35(63.64 \%) \\
20(36.36 \%)\end{array}$ & $\begin{array}{l}52(71.24 \%) \\
21(28.76 \%)\end{array}$ & $\begin{array}{l}37(68.52 \%) \\
17(31.48 \%)\end{array}$ & 0.509 & $\begin{array}{l}26(57.77 \%) \\
19(42.23 \%)\end{array}$ & $\begin{array}{l}18(62.06 \%) \\
11(37.94 \%)\end{array}$ & $\begin{array}{l}16(69.56 \%) \\
7(30.43 \%)\end{array}$ & 0.802 \\
\hline $\begin{array}{l}\text { Nocturia: } \\
\text { Positive } \\
\text { Negative }\end{array}$ & $\begin{array}{l}37(67.27 \%) \\
18(32.73 \%)\end{array}$ & $\begin{array}{l}55(75.35 \%) \\
18(24.65 \%)\end{array}$ & $\begin{array}{l}35(64.81 \%) \\
19(35.19 \%)\end{array}$ & 0.099 & $\begin{array}{l}32(71.11 \%) \\
13(28.89 \%)\end{array}$ & $\begin{array}{l}23(79.31 \%) \\
6(20.69 \%)\end{array}$ & $\begin{array}{l}18(78.26 \%) \\
5(21.74 \%)\end{array}$ & 0.111 \\
\hline $\begin{array}{l}\text { UUI: } \\
\text { Positive } \\
\text { Negative }\end{array}$ & $\begin{array}{l}38(69.09 \% \\
17(30.91 \%)\end{array}$ & $\begin{array}{l}58(79.45 \%) \\
15(20.55 \%)\end{array}$ & $\begin{array}{l}39(72.23 \%) \\
15(27.77 \%)\end{array}$ & $0.002 *$ & $\begin{array}{l}26(57.77 \%) \\
19(42.23 \%)\end{array}$ & $\begin{array}{l}20(68.96 \%) \\
9(31.04 \%)\end{array}$ & $\begin{array}{l}16(69.56 \%) \\
7(30.44 \%)\end{array}$ & 0.174 \\
\hline
\end{tabular}


Table (5): Correlation between urodynamic parameters and histopathopathological findings in both groups.

\begin{tabular}{|c|c|c|c|c|c|c|c|c|}
\hline & \multicolumn{4}{|c|}{ Group I: DO $(n=128)$} & \multicolumn{4}{|c|}{ Group II: No DO $(n=74)$} \\
\hline & Normal & Hypertrophy & Degeneration & $\begin{array}{c}p- \\
\text { value }\end{array}$ & Normal & Hypertrophy & Degeneration & $\begin{array}{c}p- \\
\text { value }\end{array}$ \\
\hline $\mathrm{FS} / \mathrm{ml}$ & $109.69 \pm 29.62$ & $102.74 \pm 28.55$ & $91.16 \pm 24.61$ & $0.011 *$ & $167.40 \pm 45.20$ & $126.66 \pm 34.20$ & $117.10 \pm 31.62$ & $<0.001 * *$ \\
\hline $\mathrm{MCC} / \mathrm{ml}$ & $264.87 \pm 77.04$ & $200.05 \pm 54.01$ & $241.40 \pm 65.18$ & $<0.001 * *$ & $305.80 \pm 82.57$ & $256.25 \pm 69.19$ & $272.50 \pm 74.12$ & 0.106 \\
\hline $\begin{array}{l}\text { Comp } \\
\mathrm{ml} / \mathrm{H}_{2} \mathrm{O}\end{array}$ & $35.57 \pm 18.44$ & $30.40 \pm 15.71$ & $32 / 45 \pm 34$ & 0.660 & $43.76 \pm 14.22$ & $39.49 \pm 7.55$ & $42.12 \pm 12.19$ & 0.633 \\
\hline
\end{tabular}

Values are presented as mean \pm SD or numbers $(\%)$

DO : Detrusoroveractivity.

MCC : Maximium cystometric capacity.

Compliance: Bladder compliance.

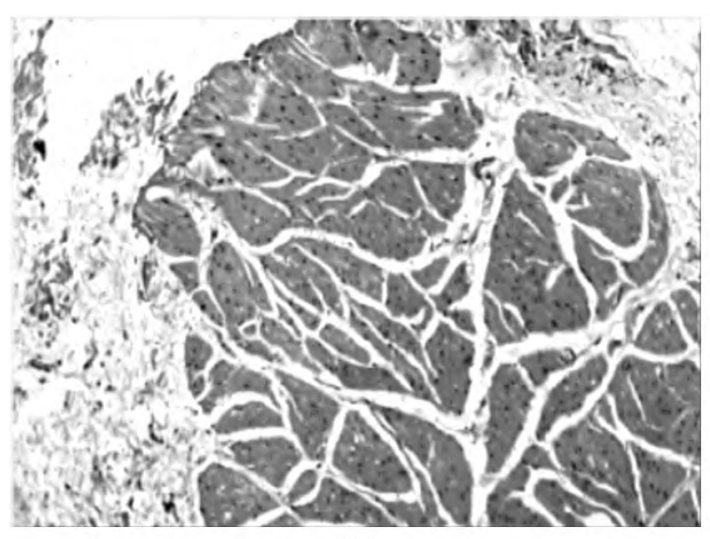

(A)

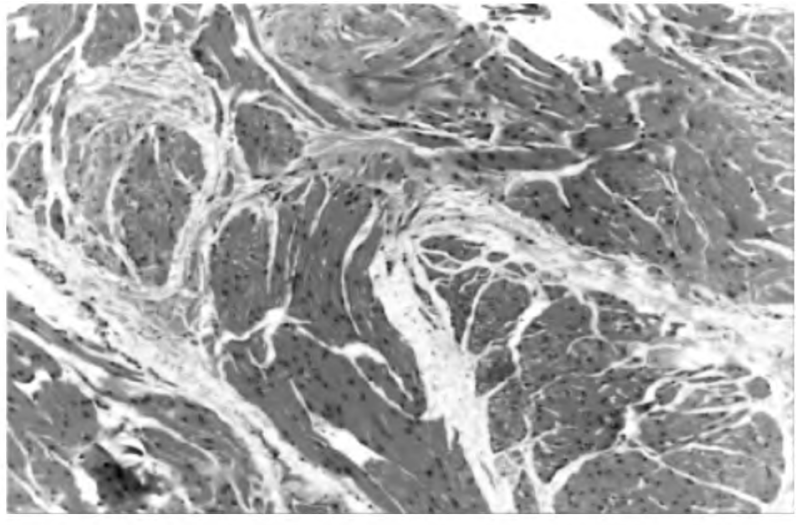

(B)

Fig. (1): (A) Normal UB section, muscle layer shows uniform size and arrangement (H \& E 200X) comparing to (B) Myohypertrophic sections of UB, increase in size of muscle bundles with areas of fibrocollagen connective tissue in between (H \& E 300X).

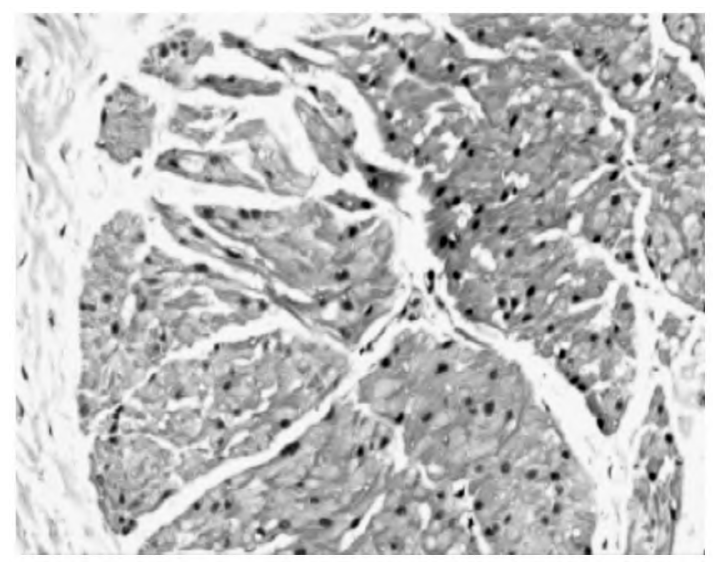

(A)

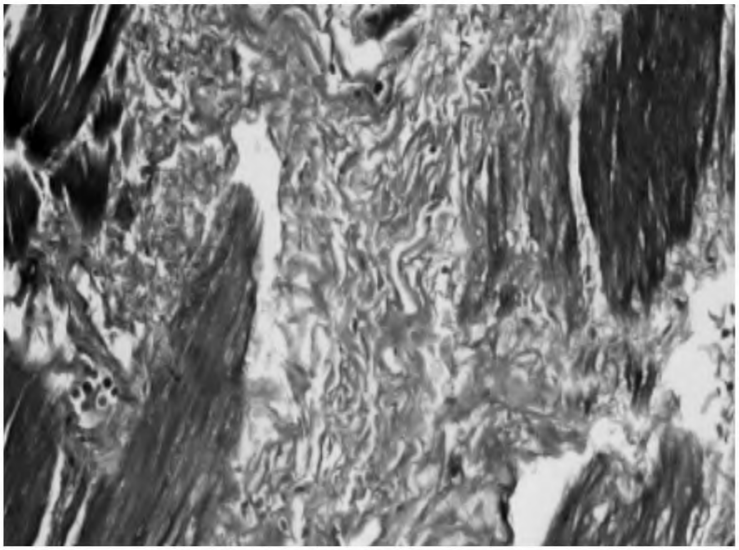

(B)

Fig. (2): Degenerative sections of UB, (A) Smooth muscle cells showing variable size and shap with areas of hyaline degeneration and cellular vacullation (H \& E 300). (B) Excess intra and extra cellular fibrocollagen infiltration blue stain (masson's trichrome 400X).

\section{Discussion}

Overactive Bladder $(\mathrm{OAB})$ is defined by the ICS as "urgency, with or without urge incontinence, usually with frequency and nocturia, if there is no proven infection or other etiology" [1]. Urodynamic study is not required routinely to make a diagnosis of $\mathrm{OAB}$, some physicians are concerned that a correct diagnosis will be missed in many patients, and they will not receive appropriate treatment because the bladder has been described as an unreliable witness [6]. The main symptom of this definition is the Urgency symptom, but it is unclear what this is based on [2]. 
In our study Detrusor Overactivity (DO) was diagnosed in $63.36 \%$ OAB patients after urodynamic studies. Similar to study by Digesu GA, et al., 2003, reported that about $55 \%$ of patients with OAB symptoms are diagnosed with DO after urodynamic examinations and Y.H. Fan et al., 2011 reported that about $60 \%$ of patients with $\mathrm{OAB}$ symptoms diagnosed with DO during urodynamic examination $[\mathbf{7 , 8 ]}$.

In our study after urodynamic studies, the incidence of DO was $43.75 \%$ and $56.25 \%$ in male and female $\mathrm{OAB}$ patients respectively in comparison to Sekido et al., [9] evaluated DO patients $75 \%$ and $36,8 \%$ in male and female OAB patients, respectively. This difference was related to population studied.

In comparison to Dekhtiar YM, et al., 2019 reported that $35.8 \%$ OAB patients, patients had detrusor overactivity during the whole period of bladder filling as a result of spontaneous detrusor contraction [10].

In our study the incidence frequency in both sexes with DO was $66.1 \%$ in male and $62.5 \%$ in female respectively without statically difference so frequency was weakly predictive of DO and not significant in associated with urgency and UUI in men. Frequency and nocturia were the major affected factors in women in contrast to men. Increasing voiding frequency did not have any effect on increasing the accuracy of diagnosis of DO.

We agree with, Al-Ghazo MA, et al., 2011 who reported that frequency was weakly predictive of DO and not significant associated with urgency, incontinence and nocturia. DO was $75.3 \%$ and $57.4 \%$ in both male and female patients respectively while interactions with urgency showed that both slightly increase the risk of other factors. In women risks of nocturia $72.2 \%$ and incontinence $79.6 \%$ were significant and further interactions showed more significant risks, namely the interactions of nocturia with either frequency or incontinence. Although UUI was significant associated with DO $66.3 \%$ in men, the interactions showed that frequency and nocturia were the major risk factors in women in contrast to men [11].

These results were near to our study; nocturia was increased significantly in female patients with DO $73.6 \%$ and in male patients with DO was increased $66.1 \%$ respectively. UUI was increased in male and female with DO as $57.1 \%$ and $63.9 \%$ respectively with highly significant.
This is similar to study by Krystal et al., 2010 who reported that nocturia was considered a valuable predictor of DO as nocturnal DO often occurs in association with nocturia in most patients diagnosed with DO and OAB. Also Hashim and Abrams, 2006 stated that urgency, UUI, and nocturia significantly increase the chances of developing DO [12,13].

However, in the study by Y.H. Fan, et al., 2011 found that nocturia alone was a significant predictor of DO, and the probability of presenting with DO increased as the severity of nocturia increased. The reason why this study does not indicate UUI as a predictor of developing DO might be due to the high incidence of UUI in their patients. Approximately $86.3 \%$ of patients were diagnosed with UUI, which is significantly higher than the rate of $25 \%$ reported in the study performed by Hashim and Abrams. 2006 Previously Khan MS, et al., 2004 reported that UUI and nocturia were more associated with DO $[8,13,14]$.

In comparison a study by, Van Brummen $\mathrm{HJ}$, et al., 2004 reported that frequency was a symptom as well as the UUI was significantly associated with the presence of DO. So frequency alone was reported to be a poor predictor of DO (31.4\%) in female $\mathrm{OAB}$ patients, and having urgency, frequency and UUI had the highest sensitivity in predicting DO $(61.0 \%)$ in females [15]

We agree with Chapple CR, et al., 2005 and Hashim and Abrams, 2006 that there is a need for a validated urgency scale that measures urgency rather than bladder sensation $[\mathbf{1 3 , 1 6}]$

Similarly Y.H. Fan et al., 2011. Found that nocturia was a significant predictor of $\mathrm{DO}$, and the probability of presenting with DO increased as the severity of nocturia increased [8].

Similarly, Hashim and Abrams, 2006 reported that UUI in men were highly correlated with underlying DO (in 60-90\%) compared to women (in 58\%) [13]

In our study, there were low bladder sensation, MCC, and bladder compliance, in both genders with $\mathrm{OAB}$ with $\mathrm{DO}$ with no significant difference.

Similar to study by Y.H. Fan et al., 2011 the bladder volume at the first desire to void and cystometric capacity were lower in both men and women diagnosed with $\mathrm{OAB}$ and DO [8].

Also we agree with Dekhtiar YM, et al., 2019 who reported reduced maximum cystometric capacity in $75.9 \%$ OAB patients, reduced bladder 
sensation in $70.8 \%$ patients, and change in bladder compliance in $43.1 \%$ patients [10].

In male patients with DO. Frequency and UUI were associated with low bladder sensation and MCC with higher significant difference and in female patients' with DO, UUI and nocturia were associated with low bladder sensation with higher significant difference and low MCC with significant difference.

Al-Ghazo MA, et al., 2011 reported that in men, the urgency and incontinence symptoms were significantly associated with the presence of DO with lower micturition and bladder sensation volumes. In women, only incontinence was significantly associated with DO with a significant effect on all urodynamic parameters examined. However, there is a significant effect of nocturia on badder compliance while the other parameters did not change significantly [11]

We agree with Chapple CR, et al., [16] reported that each symptom of frequency, nocturia, urgency and incontinence was associated with lower micturition and sensation volumes on filling cystometry. This association was not significant except for each of urgency and incontinence in men and incontinence alone in women. Although urgency is associated with a significant effect on all urodynamic parameters examined in men, there is no significant effect on the occurrence of DO.

Similar to study by Sekido et al., 2006, which reported that the severity of storage symptoms (urgency, frequency, and nocturia) were significantly associated with a reduction in MCC [9]

Guralnick et al., reported that infused volumes were significantly smaller in patients with UDSproven DO when there was a strong urge to urinate although no differences were noted in the bladder sensation at first desire to void [17].

In our study, $57.1 \%$ of male DO patients were $\mathrm{OAB}$ wet and $12.5 \%$ of male patients with no DO were also wet. $63.9 \%$ of female DO patients were $\mathrm{OAB}$ wet and $23.8 \%$ female patients with no DO were also $\mathrm{OAB}$ wet having urodynamic Stress Urinary Incontinence (SUI).

Similar to Al-Ghazo MA, et al., 2011 reported that in male, $44.9 \%$ of male $\mathrm{DO}$ patients were $\mathrm{OAB}$ wet and $10.7 \%$ were also OAB wet. In female patients $68.5 \%$ were $\mathrm{OAB}$ wet, were as $42.1 \%$ were also $\mathrm{OAB}$ wet. Also, $63 \%$ of men and $61.3 \%$ of women with urgency (OAB dry) had DO, while $93 \%$ of men and $69.8 \%$ of women with urgency and UUI (OAB wet) had DO. However, $58 \%$ of women who were OAB wet had Stress Urinary Incontinence (SUI) symptoms with $26.4 \%$ having urodynamic stress incontinence [11].

In comparison to Stewart WF, et al., 2003 found that while the prevalence of $\mathrm{OAB}$ with and without UUI in women was similar $(9.3 \%$ and $7.6 \%)$ respectively and in men the prevalence of $\mathrm{OAB}$ with UUI (2.6\%) was much lower than the prevalence of OAB without UUI (13.4\%) [18].

In our study myohypertrophic pattern and patchy areas of degenerative pattern were apperent in both sexes with DO more than those without DO with no significant difference.

UUI was the most affecting symptom in morphological changes as myohypertrophic $79.45 \%$ and degenerative $72.23 \%$ changes respectively increased with statistically significant in patients with DO in group I. Frequency and nocturia were associated with myohypertrophic changes with DO in group I more than group II. And degenerative changes were affected more by nocturia $79.31 \%$ in group II without statistically difference.

Elbadwi and associates, 1995 investigated ultrastructural changes of dysfunctional bladders with the electron microscope. Bladder tissue associated with detrusor overactivity exhibited what was termed a dysjunctional ultrastructure pattern. Conversely, a distinctive degenerative pattern has been noted in bladders with overactivity. This pattern is characterized by widespread degeneration of muscle cells and intrinsic nerves of the detrusor. Myohypertrophy ultrastructural pattern has been noted in the bladder with outlet obstruction superimposed on the pattern of overactivity [19].

Charlton RG, et al., 1999 reported the ultrastructural patterns were localized and patchy. A morphometric detrusor overactivity, using light microscopy, found areas of patchy denervation also noted highly 'punctate' structural changes in the density of nerve profiles, muscle cell hypertrophy, and more areas of collagen and elastin infiltration. Perhaps the patchy distribution and changes in the detrusor ultrastructure described in the degenerative and myohypertrophic patterns adjacent to apparently normal areas [20].

Degenerative changes were associated with low bladder sensation with statistically significant difference in group I and high statistically significant difference in group II. Myohypertrophic changes were associated with low MCC more in group I than group II highly significant difference. 
True pathological ultrastructural features may be considered as changes to the overall architecture, to the interstitium, the myocyte or to the nature of the cell junctions. In various combinations, these features have been correlated with urodynamically diagnosed voiding disorders.

However in a study by Mastropietro M, et al., 2001 was unable to correlate the ultrastructural patterns that assessed by Elbadawi's 1993 with clinical diagnoses in 24 women. The overall agreement between pattern and diagnosis was only $30 \%$. There were several possible explanations for these negative results. In $35 \%$ of patients urodynamic diagnosis was equivocal or difficult, fixation technique was not clearly explained and is acknowledged by the authors as another possible source of discrepancy $[21,23]$

In comparison to another study performed by Blatt AH, et al., 2012 in bladders from patients with bladder outlet obstruction, variations in muscle cell size and shape, abnormal fascicle arrangement and collagenosis were described, loosely corresponding to the myohypertrophy pattern originally described by Elbadawi et al., 1993 [22,23]

Ultrastructural changes of overactive bladder tissue support this theory of cell-to-cell coupling of background electrical activity. Dysfunction, denervation, and neuroenervation have been shown by Saito et al., 1993 and also in animal models. Mills et al, 2000 demonstrated denervation in 35\% of muscle bundles from overactive bladders compared with $1.5 \%$ of controls $[24,25]$.

Antunes-Lopes T, et al., 2014 reported that no consensus regarding the relationship between $\mathrm{OAB}$ and increased BWT/DWT exists. DWT/BWT was not currently recommended for diagnosis or monitoring of patients [26].

Rachaneni S, et al., 2016 suggested recently published data that routine clinical assessment of $\mathrm{BWT}$ for monitoring the effects of $\mathrm{OAB} / \mathrm{DO}$ treatment is not clinically useful [27].

There were no correlation between bladder wall thickness and predicting DO in our study.

\section{Conclusion:}

In conclusion, according to the results of the examination conducted, it was found that most patients with OAB suffer the same types of impairments of the storage function of the bladder, often associated with a decrease in the average effective bladder capacity, frequent urination, presence of urgency urination, and UUI events. Definition of
OAB based on urgency is a main better predictor in male and female patients. DO patients had been reduction of the maximum cystometric capacity, reduction of the bladder sensitivity threshold and the reduction of bladder compliance.

Frequency was weakly predictive of DO. Frequency and nocturia were the major affected factors in women in contrast to men. UUI highly significant increased in both sexes $(63.9 \%$ and $57.1 \%)$ female and male patients respectively with DO. It is important to inquire about the reproduction of symptoms during UDS and correlate this with findings during the test. There is a need for a validated urgency scale that measures urgency rather than bladder sensation. The pathophysiology of female $\mathrm{OAB}$ might be different from that of male OAB. Therefore, treatment outcomes must be evaluated for males and females, separately. Further prospective studies are needed to provide more information about the precise role of urodynamics for men and women with $\mathrm{OAB}$ symptoms and more details on structural and histopathological changes of detrusor muscle.

\section{References}

1- FIROOZI F.: Vol. 134. Switzerland: Springer International Publishing. Interpretation of Basic and Advanced Urodynamics, 2017.

2- MILSOM I., KAPLAN S.A., COYNE K.S., et al.: Effect of bothersome overactive bladder symptoms on healthrelated quality of life, anxiety, depression, and treatment seeking in the United States: Results from EpiLUTS. Urology, 80 (1): 90-6, 2012.

3- ABRAMS P., CARDOZO L., FALL M., et al.: The standardisation of terminology of lower urinary tract function: Report from the standardisation subcommittee of the International Continence Society. Neurourol. Urodyn., 21 (2): 167-78, 2002.

4- ROSIER P.F., SCHAEFER W., LOSE G., GOLDMAN H.B., GURALNICK M., EUSTICE S., et al.: International continence society good urodynamic practices and terms 2016: Urodynamics, uroflowmetry, cystometry, and pressure-flow study. Neurourol. Urodyn., 36: 1243-60, 2017.

4- ABRAMS P. and KHOURY S.: International Consultation on Urological Diseases: Evidence-based medicine overview of the main steps for developing and grading guideline recommendations. Neurourol. Urodyn., 29 (1): 1168, 2010.

5- ABRAMS P. and WEIN A.: The overactive bladder and incontinence: Definitions and a plea for discussion. Neurourol. Urodyn., 18: 413-6, 1999.

6- FLISSER A.J. and BLAIVAS J.G.: Role of cystometry in evaluating patients with overactive bladder. Urology, 60 (5 Suppl 1): 33-42, 2002.

7- DIGESU G.A., KHULLAR V., CARDOZO L. and SALVATORE S.: Overactive bladder symptoms: Do we need urodynamics? Neurourol. Urodyn., 22: 105e8, 2003. 
8- FAN Y.H., LIN C., LIN A. and CHEN K.: Are patients with the symptoms of overactive bladder and urodynamic detrusor overactivity different from those with overactive bladder but not detrusor overactivity? Journal of the Chinese Medical Association 74: 455-9, 2011.

9- SEKIDO N., HINOTSU S., KAWAI K., SHIMAZUI T. and AKAZA H.: How many uncomplicated male and female overactive bladder patients reveal detrusor overactivity during urodynamic study? Int. J. Urol., 13: 12769, 2006.

10- DEKHTIAR Y.M., KOSTYEV F.I., ZACHESLAVSKY O.M. and KUZNIETSOV D.O.: Urodynamic characteristics of lower urinary tract of patients with idiopathic overactive bladder. Urol. Ann. Jan.-Mar., 11 (1): 83-6, 2019.

11- AL-GHAZO M.A., GHALAYINI I.F., AL-AZAB R., HANI O.B., MATANI Y.S. and HADDAD Y.: Urodynamic detrusor overactivity in patients with overactive bladder symptoms. Int. Neurourol. J., 15: 48-54, 2011.

12- KRYSTAL A.D., PREUD'HOMME X.A., AMUNDSEN C.L. and WEBSTER G.D.: Detrusor overactivity persisting at night and preceding nocturia in patients with overactive bladder syndrome: A nocturnal cystometrogram and polysomnogram study. J. Urol., 184: 623e8, 2010.

13- HASHIM H. and ABRAMS P.: Is the bladder a reliable witness for predicting detrusor overactivity? J. Urol., 175: 191-4, 2006.

14- KHAN M.S., CHALIHA C., LESKOVA L. and KHULLAR V.: The relationship between urinary symptom questionnaires and urodynamic diagnoses: An analysis of two methods of questionnaire administration. BJOG, 111: 468e74, 2004

15- VAN BRUMMEN H.J., HEINTZ A.P. and VAN DER VAART C.H.: The association between overactive bladder symptoms and objective parameters from bladder diary and filling cystometry. Neurourol. Urodyn., 23: 38-42, 2004.

16- CHAPPLE C.R., ARTIBANI W., CARDOZO L.D., CASTRO-DIAZ D., CRAGGS M., HAAB F., et al.: The role of urinary urgency and its measurement in the overactive bladder symptom syndrome: Current concepts and future prospects. BJU Int., 95: 335-40, 2005.
17- GURALNICK M.L., GRIMSBY G., LISS M., SZABO A. and O'CONNOR R.C.: Objective differences between overactive bladder patients with and without urodynamically proven detrusor overactivity. Int. Urogynecol. J. Pelvic Floor Dysfunct., 21: 325e9, 2010.

18- STEWART W.F., VAN ROOYEN J.B., CUNDIFF G.W., et al.: Prevalence and burden of overactive bladder in the United States. World J. Urol., 20 (6): 327-36, 2003.

19- ELBADWI A.: Pathology and pathophysiology of detrusor in incontinence. Urol. Clin. North Am., 22: 499, 1995.

20- CHARLTON R.G., MORLEY A.R., CHAMBERS P. and GILLESPIE J.I.: Focal changes in nerve, muscle and connective tissue in normal and unstable human bladder. BJU Int., 84: 953-60, 1999.

21- MASTROPIETRO M., GEARY W., FULLER E. and BENSON J.T.: Detrusor Biopsy as a Potential Clinical Tool. Internat Urogyn. J., 12: 355-60, 2001.

22- BLATT A.H., BRAMMAH S., TSE V. and CHAN L.: Transurethral prostate resection in patients with hypocontractile detrusor-what is the predictive value of ultrastructural detrusor changes? J. Urol., 188: 2294-9, 2012.

23- ELBADWI A., YALLA S.V. and RESNICK N.M.: Structural basis of geriatric voiding dysfunction: III. Detrusor overactivity J. Urol., 150: 1668, 1993.

24- SAITO M., KONDO A., KATO T., et al.: Response of isolated human neurogenic detrusor smooth muscle to intramural nerve stimulation. Br. J. Urol., 72: 723, 1993.

25- MILLS I.W., GREENLAND J.E., McMURRAY G., et al.: Studies of the pathophysiology of idiopathic detrusor instability: The physiological properties of the detrusor smooth muscle and its pattern of innervation. J. Urol., 163: 646, 2000

26- ANTUNES-LOPES T., CRUZ C.D., CRUZ F., et al.: Biomarkers in lower urinary tract symptoms/overactive bladder: A critical overview. Curr. Opin. Urol., 24: 3527, 2014.

27- RACHANENI S., McCOOTY S., MIDDLETON L.J., et al.: Bladder ultrasonography for diagnosing detrusor overactivity: Test accuracy study and economic evaluation. Health Technol. Assess, 20: 1-150, 2016. 


\section{العلاقة بين أعراض النشاط الزائد للمثانة

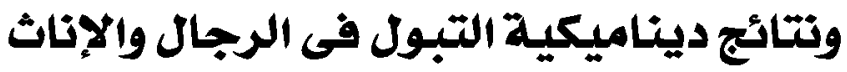

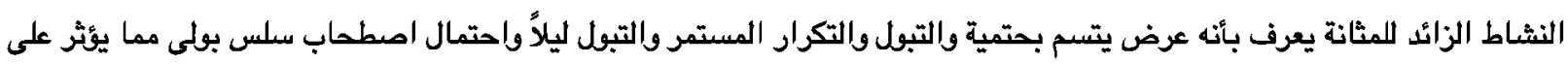

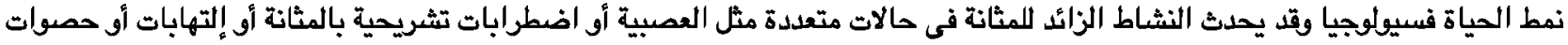
أو أودام بالمثانة.

ولتشخيص هذا العرض يتطلب عمل فصوصات قبل تثخيصها بالنشاط الزائد بالمثانة مثل أخذ التاريخ المرضى وتحليل بول وأشاعات أو منظار مثانة. وتوجد إفتراضنات متعددة لهذا العرض مسلّ:

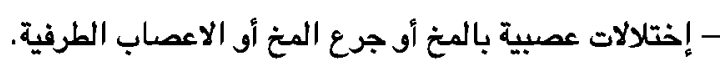
- - إضرابات بعضلة المثانة. وقد يحدث أيضاً مع إنسداد فى مجرى البول لفترة طويلة مما يؤدى إلى تضخم بعضلة المثانة أو قلة الاحساس. وقد آقترح العديد من الاطباء بأن ديناميكية التبول لا تتطلب في التثخيص المبدئى العرض. ونظراً لوجود علاقة قريبة فى تتائج ديناميكية التبول بين النشاط الزائد وإضرابات عضلة المثاثة فمن المحتمل فشل العلاج. المرضى يعانفن أكثر عندما يكون النثاط الزائد للمثانة ملازم مع تغيرات ديناميكية التبول وإضرابات عضلة المثانة عن فيرها. الفرض من البحث تجرى هذه الدراسة لمعرفة الفرق بين المرضي ذوى النشاط الزائد لعضلة المثانة والغير مصاحب باضرابات عضلة المثانة الغير عصبية في الرجال والإناث. 